\title{
Doğayla Sözleşme: Eko-merkezci Siyasetin İmkânı
}

\author{
Tuncay Önder ${ }^{1}$ \\ ORCID: 0000-0003-1266-8756
}

Öz

Doğayla sözleşme kavramı etrafındaki tartışmanın odak noktası şudur: Hukukun yegâne öznesi insan mıdır, yoksa biyosfer/ekosfer de hukukun kapsamına dâhil edilmeli midir? Ĕger insan dişındaki dünya da hukuksal bir özne olarak kabûl edilecekse, insan, ontolojik ve ahlâkî bakımdan başkaları arasında bir öğeden ibaret hâle gelecektir. Derin ekoloji ve doğayla sözleşme fikri, ekolojik sorunun çözümünü, insan dışındaki dünyanın benlik sahibi, dolayısıyla hukuk öznesi kılınmasında görmektedir. Bu bakış, hümanist bir hukuk görüşünden kozmik bir hukuk görüşüne geçişi çağırmakta, daha ötesi zorlamaktadır. Esasen doğayla sözleşme nosyonunun bizi götüreceği nihai nokta, bütün biçimleriyle hümanizmin tasfiyesidir. Doğayla sözleşme çă̆rısı, bir anlamda, insanlık tarihinin bir aşaması olarak hümanizmanın paranteze alınması talebidir. Serres, doğayla sözleşmeyi bir zorunluluk olarak görmektedir. Zorunluluğu, doğa ve insan arasında süregiden 'savaş'la temellendirmektedir. Nasıl ki toplum sözleşmesi insanlar arasındaki savaştan barışa geçişin yolunu göstermektedir, doğayla sözleşme de insanla doğa arasındaki savaşı nihayete erdirecek, barışı sağlayacaktır. Toplum sözleşmesinin siyaset ya da barbarlık biçiminde kurduğu denklem, bugün doğayla sözleşme cephesinden ekoloji ya da barbarlık biçiminde kurulmaktadır. Serres, tarihin bugünkü çatallanışını 'ölüm ya da ortak yaşam' ikiliği üzerinden formüle etmektedir. Bu makale, doğa ile sözleşme kavramın ve bu bağlamda 1980'lerden beri doğanın özneleştirilmesi konusunda tutarlı bir görüş oluşturma çabası içindeki derin ekoloji akımın birarada ele almaktadır.

Anahtar Kelimeler: Doğayla sözleşme, derin ekoloji, eko-merkezci siyaset, hümanizm.

\footnotetext{
${ }^{1}$ Doç. Dr., Ankara Hacı Bayram Veli Üniversitesi, E-mail: onder.tuncay@gmail.com

idealkent @ Kent Araştırmaları Dergisi (Journal of Urban Studies)

http://idealkentdergisi.com

Geliş Tarihi Received Date: 30.11.2019 Kabul Tarihi Accepted Date: 25.12.2019
} 


\title{
The Natural Contract: Possibility of Eco-centric Politics
}

\author{
Tuncay Önder ${ }^{2}$ \\ ORCID: 0000-0003-1266-8756
}

\begin{abstract}
The focus of the debate around the concept of the natural contract: Is human being the sole subject of law, or should the biospherelecosphere be included in the law? If the non-human world is to be accepted as a legal subject, human will become an element ontologically and morally among others. The idea of deep ecology and the natural contract sees the solution of the ecological problem in making the world outside the human being a self and therefore a subject of law. This view calls for the transition from a humanist view of law to a cosmic view of law, and further forces it. Essentially, the notion of contract with nature will lead us to the liquidation of humanism in all its forms. The call for a contract with nature is, in a sense, a demand for parentheses of humanism as a stage in human history. Serres sees the natural contract as a necessity. It is based on the ongoing war between nature and human. How that the social contract shows the way of the transition from war between people to peace, the contract with nature will end the war between human and nature and ensure peace as well. The equation established by the social contract in the form of politics or barbarism is today established in the form of ecology or barbarism from the natural contract front. Serres formulates the present bifurcation of history through the duality of 'death' or 'symbiosis'. This article contextualizes the concept of natural contract with and the deep ecology current which has had an effort to form a coherent view of the subjectification of nature since the 1980s in.
\end{abstract}

Keywords: Natural contract, deep ecology, eco-centric politics, humanism.

\footnotetext{
${ }^{2}$ Assoc. Prof. Dr., Ankara Hacı Bayram Veli University, E-mail: onder.tuncay@gmail.com

idealkent (c) Kent Araştırmaları Dergisi (Journal of Urban Studies)

http://idealkentdergisi.com

Geliş Tarihi Received Date: 30.11.2019 Kabul Tarihi Accepted Date: 25.12.2019
} 


\section{Giriş}

Luc Ferry, Ekolojik Yeni Düzen adlı kitabının önsözünde, 16. yüzyılda gerçekleşen ve taraflarından birinin 'insan dışı dünya' olduğu çeşitli yargılamalardan bahseder: Bunlardan biri, 1545'de Saint-Julien Köyü sakinlerinin Maurienne'deki piskoposluk hâkimine müracaat ederek bağlarını istilâ eden yaprak biti sürüsüne karşı açtığı dâvâdır. Köylüler, haşerelerin 'aforoz' edilmelerini ve kurallara uygun olarak nasıl uzaklaştırılacaklarına dair yolun da kendilerine bildirilmesini talep ediyorlardı. Dâvâ, yargılama usûlünün öngördüğü biçimde piskoposluk hâkiminin atadığı bir avukat tarafından savunulan haşerelerin zaferiyle sonuçlandı. Hâkim, hayvanların da insanlar gibi Tanrı tarafından yaratıldığını, bitkilerle beslenme konusunda insanlarla aynı haklara sahip olduklarını ifade ederek aforoz talebini reddetti. Kararda, köylülere topluca dua etmeleri ve Tanrı'dan günahlarından bağışlanmayı dilemeleri salık verilmişti. Aynı köyün sakinleri, 42 yıl sonra 1587'de benzer bir dava için yine piskoposluk hâkimine müracaat ederler. Hâkim, yine haşereleri savunacak bir dâvâ vekili ve ona yardımcı olacak bir avukat bulur ve piskopos naibini 1545 'deki karar emrinin uygulanması için görevlendirir. Sanık avukatlarının ustaca savunmaları karşısında Kilise yargı kurulunda daha iyi bir sonuç elde edemeyeceklerini gören köylüler uzlaşmayı seçerler ve "işbu hayvanlar için Saint-Julien bağları dışında, anılan bağları kemirmelerini ve bozmalarını önlemek için, yaşayabilecekleri yeterli bir otlama alanı hazırlama"yı kabul ederler. İçinde haşerelerin istifadesine sunulan çeşitli bitki, meyve ve ağaçların bulunduğu bu otlağı, sürekli olmak ve hiçbir zarar vermemek kaydıyla sözleşmeyle bu hayvanlara devrederler (Ferry, 2000, s.9-10).

Ferry'ye göre bu, doğanın insan dışındaki bir parçasıyla yapılan anlaşmanın, bir başka deyişle 'doğayla sözleşme' nin, ilk örneğidir (Ferry, 2000, s. 11). Bu dâvâlar, modernizm öncesi, hümanizm öncesi bir hukuksal ilişki biçimini anlatmaktadır. Hayvanlara bir dâvâ vekilinin atanması, hayvanlara mahkeme celbi çıarılması, hayvanlara yönelik aforoz talebi gibi hususlar, modern-hümanist hukukun içerebileceği hususlar değildir.

\section{İnsan-merkezci Toplum Sözleşmesi}

Fakat bu davaların üzerinden henüz bir asır geçmeden 1651 yılında yayımlanan Thomas Hobbes'un Leviathan'1 insanlarla sınırlı bir sözleşmeden, bir toplum sözleşmesinden bahsediyordu. Devleti, rasyonalist bir temelde izaha gi- 
rişen Hobbes, onu insanın hareket yasasından türetiyordu. Hobbes'a göre bütün canlılarda -insanda ve hayvanda- ortak olan iki hareket biçimi vardır. Birincisi, doğumla başlayan ve hayat boyunca kesintisiz devam eden hayatî harekettir. Kan dolaşımı, soluk alıp verme, sindirim, vb. Hayatî hareketlerin gerçekleşmesi için bir muhayyileye, muhayyilenin yardımına ihtiyaç yoktur. İkincisi ise, iradî ya da hayvanî harekettir. Gitmek, konuşmak, vurmak, el-kol oynatmak gibi bu hareketler önce zihinde tasarlanır. Gitmek, konuşmak, vurmak gibi iradî hareketler, daima, nereye, ne yoldan ve neyi gibi bir ön düşünceye dayandıkları için, muhayyile, bütün iradî hareketler için ilk içsel başlangıçtır. Hobbes, iradî eylemin öncesinde insan vücudunda beliren küçük hareket başlangıçlarını 'çaba' olarak adlandırır (Hobbes, 2017, s. 48-49).

Hayatî ve iradî/hayvanî hareketler, insanla hayvanı ayırmaya yetmez. Hobbes, insanı üstün kılan ve hayvanlarda bulunmayan iki özellikten söz eder: Konuşmak ve geleceği düşünmek/öngörmek. Konuşma, doğadan kaynaklanan bir yetenek/potansiyel değildir. İnsan kelimeleri kendi iradesiyle oluşturur ve onlar aracilığıyla konuşur. Dil, konuşma, akıl ve bilime, dolay1sıyla doğal olanın, doğanın dışına çıkma kapasitesine işaret eder. Hayvanlardan farklı olarak insan kavramsal bir dünyaya sahiptir. Yapay varlıklar olan devleti ve toplumu bu dünyadan hareketle inşa eder. İnsan aklını kullanarak geleceği öngörebilir. Bu kaabiliyet, insanlarda geleceğe yönelik güven aray1şının da temelini oluşturur (Hobbes, 2017, s. 33-35; Ağaoğulları, s. 439-440). Hobbes'çu doğa durumundaki "herkesin herkesle savaşı" bu sebeple sürdürülebilir değildir. İnsanlar, buradan barışa doğru giderler ve sözleşmeyle siyasal toplumu var ederler.

Siyasal toplum, doğal olanın aşılmasıdır. İnsanlar doğal durumdan toplum durumuna, savaştan barışa, barbarlıktan uygarlığa geçerken, aklın genel kuralı olan doğal yasaya uyarlar ve barışı ararlar. Barışın gereği, doğal haklardan vazgeçmektir. Hobbes'ta doğa durumunda geçerli bir doğal yasa yoktur. Doğal durum, doğal hak üzerine kuruludur. Doğal hak, insanın; kendi hayatını korumak için kendi gücünü dilediği gibi kullanmak ve, kendi muhakemesi ve aklı ile, bu amaca ulaşmaya yönelik en uygun yöntem olarak kabul ettiği her şeyi yapmak özgürlüğüdür. (...) Özgürlük'ten kelimenin doğru anlamıyla dış engellerin yokluğu anlaşlır. (...) Hak, yapmak ve yapmamak özgürlüğünden oluşur; Yasa ise bunlardan birini tesbit ve ilzam eder: yani, yasa ve hak, ayn konuda birbiriyle tutarlı olmayan yükümlülük ve özgürlük kadar ayrı şeylerdir (Hobbes, 2017, s. 103-104). 
Locke (2018, s.40-43) Hükümet Üzerine İkinci İnceleme'nin “Mülkiyet Üzerine" bahsinde insan ve insan dışı dünya arasındaki ilişkiyi şöyle kurar:

Dünyayı insanlara ortaklaşa veren Tanrı, onlara aynı zamanda Dünyayı, Yaşamdan en üst yararı ve rahatlığı sağlayacak biçimde kullanmaya yarayacak aklı da vermiştir. Yeryüzü ve yeryüzündeki her şey İnsanlara varlıklarının Desteklenmesi ve Rahata kavuşturulması için verilmiştir. (...) Yeryüzü ve diğer bütün ast yaratıklar İnsanların tümüne ortaklaşa ait olmasına rağmen her insan yine de kendi Kişisi üzerinde bir Mülkiyete sahiptir. Bunda kişinin kendisinden başka Hiç Kimsenin hakkı yoktur. Kişinin Bedeninin Emeği ve Ellerinin İşi diyebiliriz ki tam anlamıyla kendisinindir. Doğanın sağladığı ve içinde muhafaza ettiği şeylerden, İnsan, Emeğini kattığı ve kendi özüne ait olan bir şeyleri birleştirdiği şeyi bu Durumun dışına çekip çıkarır ve bu yolla bu şeyi Mülkiyeti haline getirir. (...) Mülkiyet olmaksızın Ortaklaşa olanın kullanımı sözkonusu olamazdı. Dolayısıyla şu ya da bu bölümü almak bütün Ortakların açık onayına bağlı değildir. (...) Atımın ısırdığı Otlar, Hizmetlimin kestiği çimenler, herhangi bir yerde kazdığım maden cevheri hiç kimsenin onayı ya da dağıtımı olmaksızın benim Mülkiyetim haline gelir. (...) Dolayısıyla bu akıl Yasası, geyiği, onu öldüren Kızılderili'nin yapar. (...) İçimizde bile birilerinin avlamakta olduğu Tavşanın, onu kovalamaca sırasında takip eden kişiye ait olduğu düşünülür. (...) bir hayvan üzerinde hayvanı bulmak ve izlemek için yeteri kadar emek harcamış olan biri bu yolla hayvanı ortaklaşa olduğu Doğa durumundan çekip çıkarmıştır ve bir Mülkiyet başlatmıştır.

Locke için de döneminin ruhuna uygun biçimde, hak öznesi olan tek varlık insandır. Mülkiyet, insanın doğal hukuktan kaynaklanan hakkıdır. Mülkiyetin biri dar, diğeri geniş iki anlamı vardır. Dar anlamda mülkiyet, maddî mülkiyettir. Locke'a göre insanın kendini idame ettirebilmesinin gerek şartı, mülkiyet sahibi olabilmesidir. Hayatî ihtiyaçlar için bile mülkiyet gereklidir. Maddî mülkiyetin yolu, mülkiyetin konusu olan varlığın/eşyanın içine katılan emekten geçmektedir. Geniş anlamda mülkiyet ise, maddî mülkiyete olarak, yaşama ve özgürlük hakkını da içerir. Bu haklar insana özgüdür; akıl ve ahlâkî ilkelerden oluşan doğal hukuktan çıarsanabilirler. Locke, sivil/uygar yönetiminin temelinde de geniş anlamda mülkiyeti koyar. Siyasal toplum, geniş anlamda mülkiyetin korunması gereğinden türetilir.

Rousseau da insanla insan dışı dünya arasındaki farkı doğa ile özgürlük arasındaki karşıtlıkla temellendirir. Doğal-vahşi-özgür insan, konuşmuyor ve toplumsal ilişki geliştirmiyor olsa da hayvandan farklıdır. Rousseau'ya göre, hayvanların duyuları varsa fikirleri olduğu da söylenebilir. Hattâ hay- 
vanlar, fikirlerini bir dereceye kadar sıraya koyup düzenleyebilirler. Bu bağlamda insanı hayvan karşısında üstün kılan şey, kavrama, anlama ve yarg1lama yetisinden ziyade onun özgür olma vasfıdır. Doğa hayvanlara emreder ve hayvan bu emre uyar. İnsan da aynı etki altındadır, fakat o bu emre uymakta ya da direnmekte kendisini özgür bilir (Rousseau, 1990, s. 103). Hayvanlarda "doğanın yön verdiği, ustalıkla yapılmış bir makine"yi gördüğünü belirten Rousseau, bir farkla insan makinesinde de benzer şeyler gördüğünü söyler. Bu fark, hayvanın bütün işlerinde her şeyi sadece doğanın yapması, insanın ise kendi işlerinin yapılmasına özgür bir unsur olarak katılmasıdır: "Biri, içgüdüsüyle, ötekiyse özgür eylemiyle seçer ya da reddeder; bunun sonucu şu oluyor: Hayvan, kendisine hükmeden kuraldan uzaklaşması kendisi için daha yararlı olduğu zaman bile, sapamaz; insan ise, kendi zararına olsa bile, çoğu kez uzaklaşabilir" (Rousseau, 1990, s. 102-105). Hayvan, davranışlarını yönlendiren doğal kuralın dışına çıkamaz. İçgüdü adlı bir kodlamayla programlanmıştır. Determinizme tabidir. İnsan ise bunun tam tersi olarak, belirlenmemişliktir. İnsan özgürdür ve bu özgürlük, kötülügün mümkün olmasıdır. İnsan iyiyi görür, ama kötüyü seçebilir; doğa karşıtı bir varlık oluşunun formülü tam da budur. İnsanın özü, bir öze sahip olmamaktır (Ferry, 2000, s. 37-38)

Rousseau, Descartes'in hümanizmini ve makine-hayvan kuramını benimsemiş görünmektedir. Ona göre, insanla hayvanı ayıran tartışma götürmez bir gerçek de insanın "yetkinleşme, olgunlaşma yetisi"dir: "Bu yeti şartların da yardımıyla bütün öteki yetileri art arda geliştirir ve bizde gerek tür olarak gerek kişi olarak bulunur, oysa bir hayvan bütün hayatı boyunca değiştiremeyeceği kesin şekli birkaç ay içinde alır ve bu hayvanın türü de bin yılın sonunda bu birinci yılının sonunda olduğu gibi kalır" (Rousseau, 1990, s. 104). Hayvanlar tarihsizdir. Çünkü hayvanlardaki doğal normlardan sapma, bir kültür dünyası doğurmaz. Çünkü doğanın buyruklarına karşı duruş, bir tarih inşa etmek üzere, kuşaktan kuşağa aktarılmaz. İnsanın hayvandan farkı, doğanın karşısında kültürü var etmesi ve aktarmasıdır. İnsanı tarihlendiren şey de budur. Eğer kültür olmasaydı, insanlar da hayvanlar gibi tarihsiz olurlardi.

\section{Bütüncü Görüş Olarak Ekolojizm}

Her ideoloji gibi ekolojizm de bize bir tarih anlatısı sunar. Bu anlamda ekolojizm, tarihin doğa-insan, doğa-toplum ilişkileri ekseninde yeniden okunma- 
sıdır. Fakat ekolojizmi diğer bütün ideolojilerden ayıran, farklılaştıran bir hususun altını kalınca çizmek gerekir. Bu husus, ekolojizmin sadece insanı ve toplumu referans almaması, aynı zamanda insan dışındaki doğal dünyadan çıkarsanan ilke ve normlara dayanmasıdır. Bilim olarak ekoloji, biyolojinin bir alt dalıdır. Yüzyılı aşan bir geçmişe sahip olmakla birlikte, daha sık gündeme gelmesi ve popüler bir nitelik kazanması 1970'li yıllara rastlamaktadır. Ekoloji hareketinin yükselişiyle birlikte, ekoloji de bir bilim olmaktan bir dünya görüşü olmaya doğru evrilmiştir. Ekolojinin gördüğü kitlesel ilgi, bir kurtuluş yolu göstermesinde değil, bir felaket teorisi olmasında aranmalıdır (Zeka, 1985, s. 89). Çünkü ekoloji, Batı bilimciliğinin indirgemeci yaklaşımı karşısında sahip olduğu bütüncü yaklaşımla (Kışlalıŏ̆lu ve Berkes, 1990, s. 28) insanlığı bütünüyle felâkete sürükleyecek çelişkileri ortaya koymaktadır.

Ekoloji kavramı bugün yaygın olarak biyolojik değil, normatif bir çağrışıma, içeriğe sahiptir. Bunun kökeninde, ekolojinin baştan beri zımnen içerdiği 'siyasal öz' yatmaktadır (Bramwell, 1989, s. 4). Pepper (1999, s. 184), ekoloji biliminin kurucu babası Heackel' in yaklaşımının açık bir biçimde 'siyasal' olduğunu düşünmektedir. Ekolojinin ampirik anlamı, doğa bilimlerinden kaynaklanmaktadır; insan toplumlarına ilişkin gözlemlerden ve öngörülerden yola çıkılarak geliştirilmemiştir. Fakat ekoloji bilimi, ekolojistlerin gözlemlerini insan toplumlarını kapsayacak biçimde genişletmesinden önce de insan ve hayvanı karşılaştırılabilir olarak gören bir etiğe sahipti. İşte ekolojinin içinde saklı politik anlam tam da bu noktada belirginlik kazanmaktadır. Bu aşamada bir uyarının yapılmasında fayda var: Ekolojizm, bir bilim olarak ekolojinin derin izlerini taşımaktadır; ancak ekolojizm, biyolojik analizden hareketle üretilmiş bir siyasal söyleme indirgenemez (Simonnet, 1993, s. 29).

Ekolojizmin doğa kavrayışı toplumsal, siyasal ve kültürel içerimlere sahiptir. Doğa ve onun tarihi, 'toplumsal' olandan ayrıştırılamaz (Çiğdem, 1997, s.31); doğa-insan ilişkisi, toplumsal arka planından soyutlanarak ele al1namaz. Çünkü insanın doğaya müdahalesi, bu müdahale hangi kültürel kodlar çerçevesinde gerçekleşirse gerçekleşsin, doğayı toplumsallaştırmaktadır. Yani, ekolojizmin bakış açısından doğa-insan ilişkisi, başlı başına bir toplumsal ilişkidir. Zira doğa, insan zihnine dışsal bir kategori değildir. Doğa hep doğadır; ancak insanlığın doğa kavrayışı sabit değildir. Bu anlamda doğa, doğallığ1 içinde kavranabilir olmaktan uzaktır. İnsanın doğa ile ilişkisi, her zaman zihinsel, kültürel, ideolojik bir bağlam içinde gerçekleşir. 


\section{Doğayla Sözleşme Arayışı Olarak Derin Ekoloji}

Derin ekolojistler ${ }^{3} 1980^{\prime}$ lerin başından beri, yaklaşık 40 yıldır, doğayı hukuk öznesi olarak tanımlayan tutarlı bir doktrin inşa etmek için uğraşmaktadırlar. Derin ekolojistler, genel itibarıla eski ‘toplum sözleşmesi'nin yerini, bütün evreni bir hukuk öznesi olarak kapsayacak bir doğa sözleşmesine bırakması gerektiğini düşünmektedirler. Derin ekoloji, doğayı ve insanı birbirinden ayıran ve farklılaştıran insan-merkezci düalizmi kesin bir biçimde reddeder. İnsan ve doğayı 'bir' ve 'bütün' olarak ele alır (Pepper, 1999, s. 17). İnsanı, başka hiçbir şeyden ayırmadığı gibi doğadan da ayırmaz. Doğayı birbirinden bağımsız nesnelerin bir araya toplanması biçiminde değil, karşılıklı bağımlılık ve bağlantı içindeki bir olgular ağı olarak değerlendirir. Derin ekoloji, insan olmayan doğanın kendinde/içsel bir değere sahip olduğu fikrinden hareket etmektedir. Bu çerçevede insan, hayat ağının iplerinden yalnızca biri konumundadır. Doğanın kendindeki değerin farkında oluş, doğa ile insan benliğinin 'bir'liğine ilişkin derin ekolojik bilinçten kaynaklanmaktadır (Capra, 1995, s. 20).

Derin ekoloji, eko(biyo)-merkezci ${ }^{4}$ bir yaklaşıma sahiptir. Eko-merkezcilik, doğanın ve doğadaki çeşitliliğin korunmasını, insana getireceği yararla değil, doğanın kendisindeki değerle temellendirir. Eko-merkezci ya da biyomerkezci bir pozisyon, insanın iyiliğinin yanında, insan olmayan dünyanın iyiliğinin gözetilmesini de zorunlu kılmaktadır (Barry, 1994, s. 371). İnsanmerkezcilik (antropocentrism), kabaca iki varsayım üzerine inşa edilmiştir. Birincisi, insan ve insanın değerleri, bütün değerlerin kaynağıdır. İkincisi, insan

\footnotetext{
${ }^{3}$ Derin ekolojinin isim babası Norveçli filozof Arne Naess'dir. Naess, derin ekoloji-sığ ekoloji ayırımını ilk defa 1972 yılında Bükreş'teki "Üçüncü Dünyanın Geleceği” Konferansında yapmıştır. 1973 yllında yayınlanan The Shallow and the Deep, Long-Range Ecology Movements: A Summary adlı makalesiyle derin ve sığ ekolojiler arasındaki farklılıkları ortaya koyarak derin ekolojinin ilkelerini belirlemiş, 1986 tarihli The Deep Ecological Movement: Some Philosophical Aspects makalesiyle de bu ilkeleri daha ayrıntılı bir hâle getirmiştir. Naess dışında derin ekolojiye en çok katkı yapan isimler Gary Snyder, Bill Devall ve George Sessions'dır. Roussopoulos (1993, s. 75), derin ekoloji literatürünün geniş ama fazlasıyla tekrarcı olduğu görüşündedir.

4 Derin ekolojinin yaklaşımı, eko-merkezcilik yanında biyo-merkezcilik olarak da adlandırılmaktadır. Bu yaklaşımda, insana "bir dağ gibi düşünmek"i öğütleyen Aldo Leopold’un Toprak Etiğinin çok önemli bir katkısı vardır. Leopold'un 1949'da yayınlanan A Sand County Almanac adlı derlemesinde yer alan A Land Ethic başlıklı deneme, insanın toprakla ilişkisinin "ekonomik" bir ilişki olduğu, bunun etik ve estetik bir ilişkiye dönüştürülmesi gerektiği üzerinde durmaktadır. Amerikan ekoloji hareketi üzerinde çok etkili bir isim olan Leopold, eko-merkezci bakışıyla derin ekolojinin de 'fikir babası' olarak nitelendirilmektedir. Bu konuda bkz. (Leopold, 1991; Ünder, 1996, s. 205-210).
} 
arzularının tatmini için doğanın kullanılması ve manipüle edilmesi meşrudur. Dolayısıyla insan-merkezcilik, insan dışında ahlâkî bir özne tanımaz. Eko-merkezcilik, tam aksine, insan olmayan dünyayı da ahlâkî topluluğun bir parçası hâline getirmektedir. Manes (1990, s. 141), derin ekolojinin ekomerkezciliğini "İkinci Copernicus Devrimi” diye nitelendirmektedir. Nasıl ki, Birinci Copernicus Devrimi yer-merkezli (geocentric) dünya görüşünü tasfiye etmiştir, derin ekoloji de insan-merkezci dünya görüşünün yıkılışına işaret etmektedir. Bu çerçevede derin ekoloji, doğaya ilişkin yeni bir dil ile konuşmayı zorlamaktadır. Derin ekolojinin biyo-merkezciliği, insanın doğadan ayrı ve onun üzerinde değil, içinde olduğuna dair yeni bir kozmik/ekolojik metafizik gerektirmektedir. İnsan ile doğanın bütünleşmesine yönelik bu metafizik, doğanın Gaia olarak kişileştirilmesini, ona bir benlik atfedilmesini içermektedir. Gaia, Yunancada Yerana veya Yer Tanrıçası anlamına gelmektedir. James Lovelock tarafindan 1970'li yıllarda geliştirilen, “Gaia hipotezi"ne göre, yerküre yalnızca bir oturma alanı değil, bir hayatı olan, nefes alıp veren canlı bir organizmadır; dünya, rastgele biraraya gelmiş hayat biçimlerinin toplamı değildir (West, 1994, s. 113-120). Naess, “Derin Ekoloji Hareketi'nde biz kendimizi biyosentrik ya da ekosentrik olarak kabul ederiz. Bize göre temel birim ekosferdir, bütün gezegendir, Gaia'dır ve her canlı varlığın doğal bir değeri vardır" (Naess, 1994, s. 14) derken, biyo-merkezcilik ile bu ekolojik metafizik arasındaki ilişkiye gönderme yapmaktadır.

Derin ekolojinin insan-doğa ilişkisine dair önkabûlleri şöyle özetlenebilir (Naess, 1995c, s. 68): (1) Yeryüzündeki insanların ve insan olmayan hayatın iyi durumda olması ve serpilip gelişmesi kendinde değerlidir -içsel bir değere sahiptir. Bu değerler, insan olmayan dünyanın insanın amaçları için yararlı olmasından bağımsızdır. (2) Hayat formlarının zenginliği ve çeşitliliği, bu değerlerin gerçekleştirilmesine katkıda bulunur. Bu zenginlik ve çeşitlilik, aynı zamanda kendi içinde değerlidir. (3) Hayati ihtiyaçlarını karşılamak dışında, insanların bu zenginliği ve çeşitliliği azaltmaya hiçbir hakları yoktur. (4) İnsan hayatının ve kültürlerinin serpilip gelişmesi, insan nüfusunun ciddi ölçüde azaltılmasıyla mümkün olabilir. İnsan olmayan hayatın serpilip gelişmesi de daha az bir insan nüfusunu gerektirir. (5) Halihazırda, insanın insan olmayan dünyaya müdahalesi aşırı düzeydedir ve durum hızla kötüleşmektedir.

Derin ekoloji iki nihaî ilkeye sahiptir. Bunlardan biri, kendini gerçekleştirme (self-realization) ilkesidir (Naess, 1995d, s. 80). Derin ekoloji bağlamında kendini gerçekleştirme, insana özgü olmayan, insan ve insan dışındaki bütün varlıklar için geçerli bir haktır. İnsanın ve insan olmayan türlerin kendi doğal 
tarzına göre yaşama ve potansiyellerini geliştirme iradelerine işaret eder. Naess'e göre kendini gerçekleştirme, doğadaki çeşitliliği (diversity) en üst düzeye çkarmayı gerektirir. Çeşitlilik, hayatın potansiyellerini artırır, yeni hayat biçimlerine ve bu biçimlerin zenginliğine fırsat verir. Bu bağlamda, kendini gerçekleştirme nihaî ilkesinden çıkarsanabilecek ilk norm, 'azamî çeşitlilik'tir. Çünkü bir hayat formunun daha yüksek bir kendini gerçekleştirme düzeyine varması, diğer formların kendini gerçekleştirmeleriyle doğrudan ilişkilidir. Bir başka deyişle, azamî kendini gerçekleştirme, "her hayat biçiminin manifestolarının azamileştirilmesi"ne tekabül etmektedir. Kendini gerçekleştirme ilkesinden çıkarsanacak ikinci norm ise 'azamî ortak hayat'dır (maximum symbiosis) (Naess, 1995c, s. 80). Yani kendini gerçekleştirmenin en üst düzeye çıkarılması, 'evrensel ortak yaşarlık'la mümkün olabilmektedir. Darwinist şemadaki hayat için çatışma ve en çok uyum sağlayanın hayatta kalması fikri, öldürme, sömürme ve bastırma yeteneğinden çok, karmaşık ilişkilerde bir arada varolma ve işbirliği yapma yeteneği biçiminde yorumlanmalıdır. Bu çerçevede, "yaşa ve yaşama izin ver" ilkesi, "ya sen ya ben"den çok daha güçlü bir ekolojik ilkedir (Naess, 1995d, s. 152).

Kendini gerçekleştirmeyle ilgili çok önemli bir kavram da 'özdeşleşme' dir (identification). Özdeşleşme kavramı, insanın kendini gerçekleştirme süreciyle ilişkilidir. Kendini gerçekleştirme, insan benliğinin bir bütün olarak kozmos/evren düzeyine varana kadar hep kendinden daha büyük bütünlerle özdeşleşmesini gerektirmektedir. Hümanist etikte doğa, bu benlik genişlemesinin dışında bırakılmıştır. Oysa doğa insan için bir evdir ve ekolojik benlik insan olmayan doğayla özdeşleşmeyi de içermektedir (Naess, 1995b, s. 225226). Kendini gerçekleştirme ile özdeşleşme arasında doğru oranlı bir ilişki vardır. Bu anlamda kendini gerçekleştirme, insan benliğinin doğal benliğin organik bütünlüğü içine dağılmasına karşılık gelmektedir (Luke, 1988, s. 73). Benliğin ancak başka benliklerle özdeşleşip bütünleşebildiği düşünülürse, derin ekolojinin doğaya bir benlik atfettiği söylenebilir. Dolayısıyla derin ekoloji, animistik bir yönelişi potansiyel olarak barındırmaktadır. Ünlü "dağ gibi düşünmek" sloganı da bu durumun bir göstergesi sayılabilir. İnsanın doğayla özdeşleşmesinin en önemli sonucu, doğanın, 'nesne' biçiminde algılanmaması, bir benliğe sahip 'özne' konumuna yükselmesidir.

Derin ekolojinin ikinci nihaî ilkesi, 'biyosferik eşitlik' ilke/normudur. Bu ilke, bütün hayat formlarının içsel bir değere ve kendini gerçekleştirme düzeyinde bir eşitliğe sahip olmasının doğal sonucudur. Biyosferik eşitlik, insanın hayat formlarının yalnızca dar bir bölümü olduğu anlayışına dayanmaktadır. 
Ekolojik bilinçlilik açısından doğadaki bütün varlıkların eşit haklara sahip olduğu düşüncesi, sezgisel olarak anlaşılabilir ve açık bir değer-aksiyomdur. İnsanın daha büyük bir bütüne bağlllığını görmezden gelmek ve efendi-köle rolüne sarılmak, insanın kendine yabancılaşmasına yol açacaktır (Naess, 1995d, s. 152). Ancak biyosferik eşitlik normu, 'mutlak' bir eşitliğe değil, 'ilkece' bir eşitliğe işaret etmektedir. Çünkü gerçek pratik, bazı öldürmeleri, kullanmaları ve bastırmaları zorunlu kılmaktadır. Bir ekosistem içindeki herhangi bir organizma, varlı̆̆ını sürdürebilmek için başkalarını besin veya sı̆̆ınak olarak kullanmak zorundadır. Aksini düşünmek, bütünüyle hayatın yok olmasına rıza göstermek demektir. Bu çerçevede biyosferik eşitlik ilkesi, esas itibariyle "insanın diğer canlı türlerinin yaşamına ve yaşama alanına ve kendilerini kendi doğal tarzlarına göre geliştirme hakkına müdahalesini 'en az' düzeyde tutmasını, 'gereksiz' öldürme ve kullanmalardan kaçınmasını emreder" (Ünder, 1996, s. 203).

Naess, biyosferik eşitliğin bütün türlerin mutlak eşitliği anlamına gelmediğini anlatmak için, 'eşit haklara sahip olmak' ile 'eşit kendini gerçekleştirme hakkına sahip olmak' arasında ayırıma gitmektedir. Ona göre, bütün hayat formları için evrensel yaşama hakkından ve kendini gerçekleştirme düzeyinde eşitlikten söz etmek, bütün türlerin eşit olduğunu savunmaktan farkl1dır. Her türün ihtiyaçlarının ve potansiyellerinin eşit olmadığı, apaçık bir gerçektir. Naess, biyosferik eşitliğin tek başına bir norm gibi değerlendirilmemesini, bir normlar bütününün parçası olarak ele alınmasını istemektedir. $\mathrm{Bu}$ norm tek başına anlaşılmak istenirse, eşitlik gereği insanın ihtiyaçlarının insan olmayan türlerin ihtiyaçlarından asla öncelikli olamayacağı gibi yanlış bir sonuca varılabilir. Oysa biyosferik eşitlik normu, temelde, insanın hayatî olmayan ihtiyaçlarıyla insan dışındaki türlerin hayatî ihtiyaçları arasında bir çatışma olması durumunda, bunların karşılaştırılması gerektiğini ifade etmektedir (Naess, 1992, s. 166-171). Derin ekoloji, biyosferik eşitlik ilkesi bağlamında insan-merkezci etikteki toplumsal eşitlik fikrini biyosfer düzeyine taşıyarak bir tür “biyo-demokrasi” ye (Stark, 1995, s. 262) yönelmektedir. Böylelikle doğa-insan ilişkisini etik bir temele oturtmakta, ahlâkî topluluğun s1nırlarını insan olmayan dünyayı da içerecek biçimde genişletmektedir. İnsan ve doğa arasındaki özne-nesne, amaç-araç, efendi-köle ilişkisini ortadan kaldırarak ahlâkî bir ilişkinin önünü açmaktadır.

\section{Eko-merkezci Siyasetin Şifreleri}

Derin ekolojinin iyi tanımlanmış, kapsamlı bir siyasal programı olduğu söylenemez. Naess'in siyasete yaklaşımı, "herşey siyasetle ilgilidir, fakat siyaset 
herşey değildir" (Naess, 1992, s. 131) teziyle özetlenebilir. Ona göre derin ekoloji, siyasete, onun doğasını değiştirebilecek düzeyde yenilikler getirmektedir. Bunların en önemlisi, siyaseti toplum düzeyinden biyosfer/ekosfer düzeyine taşımasıdır. Derin ekoloji, insan-merkezli ve kısa dönemli argümanları reddederek, yeryüzü merkezli ve uzun dönemli argümanları öne çıkarmaktadır. Bu ayn zamanda, "çevre içinde insan" ve "ekosistemler içinde siyaset" düşüncesine yönelmeyi içermektedir. Derin ekoloji, bu çerçevede, eko-politik temaları da genelleştirmektedir. "Kaynak", "hayat kalitesi" gibi kavramları, insan için olmaktan çıkarmakta, insan ve insan olmayan tüm canlılar için geçerli hâle getirmektedir ( Naess, 1995a, s. 452).

Biyosferik eşitlik normunu 'organizmik demokrasi' diye niteleyen Merchant (1992, s. 86) da siyasetin alanına ilişkin genişlemeye işaret etmektedir. Kendini gerçekleştirme ilkesi bağlamında insan olmayan doğanın haklarından sözetmek, doğayı bir nesne olmaktan çıararak, özne konumuna taşımaktadır. Serres (1994)'in 17. ve 18. yüzyıl filozoflarının toplum sözleşmesi düşüncesine benzeyen 'doğayla sözleşme' fikri de doğanın özneleşmesiyle ilgilidir ve doğayı hukuken özneleştirmeyi amaçlamaktadır. Doğayla sözleşme, insan ile doğa arasındaki ilişkinin tek yönlü ve eşitsiz bir ilişkiden uzaklaşarak bir ortak yaşam ilişkisine dönüştürülmesini ifade etmektedir.

Derin ekoloji, toplumsal örgütlenme bakımından yerel özerklik ve ademi merkeziyet ilkelerini benimsemektedir. Temel toplumsal birim 'biyobölge'dir. Biyo-bölge, insani, ekolojik bir topluluk, bir yuvadır. İnsanların yaşadığı yeri ve çevresinde insanların, yetişen bitkileri, yaşayan hayvanları, akarsuları, ormanları ve özelliklerini tanıdıkları bölgeyi ifade etmektedir. Biyo-bölgecilik (bio-regionalism), insanların toprakla ve mevsimle uyum içinde yaşamaları fikrine dayanmaktadır. Doğal dünyanın, yerel çevre ve topluluktaki siyasal, toplumsal ve ekonomik hayatı belirlemesine işaret etmektedir (Barry, 1994, s. 378). 'Doğa en iyisini bilir' varsayımından hareket eden biyo-bölgeciliğin radikal yönü, toplumsal örgütlenmenin 'doğal sınır'ları ile 'siyasal sınır'ları arasındaki çelişkiyi ortaya koymasıdır.

Dobson (2000, s. 43-44) derin ekolojinin güçlü bir siyasal bir potansiyel taşıdığı görüşündedir. Naess' in gerçek hayatın bazı öldürme ve kullanmaları zorunlu kılmasından hareketle biyosferik eşitlik ilkesine eklediği 'ilkece' hükmü, derin ekolojinin siyasal olmadığı iddia edilen doğasını siyasallaştırmaktadır. Çünkü öldürmenin, kullanmanın ve sömürünün sınırının ne olacağı tartışması, pratik bir tartışmadır ve ekolojik siyasetin de özünü yansıtmaktadır. Bu tartışmanın insan eylemini bütünüyle kuşatan bir tartışma olduğu şüphe götürmez. 


\section{İnsan: Doğanın Doğal Olmayan Parçası}

Hümanizm karşıtlı̆̆ ya da insan sevmezlik, derin ekolojiye yöneltilen eleştiriler içinde önemli bir yer tutmaktadır. Mellor, insanın ve toplumun gelişmesinin, doğal dünyanın varoluş hakkını gözeten bir sınırı olması gerektiği fikrinin saygıyla karşılanabileceğini, ancak derin ekolojinin insan-doğa ilişkisini yeniden sağlıklı bir zemine kavuşturma amacını aşan boyutlara sahip olduğunu belirtmektedir. Bu, insanî ortamın kaybolması, daha ötesi reddedilmesi tehlikesidir (Mellor, 1993, ss. 102-103). Bu çerçevede, derin ekolojinin insanı 'doğanın doğal olmayan parçası' konumuna sürüklediği belirtilmektedir. Hümanizm karşıtlığı esas alındığında, derin ekolojinin biyo-merkezci olmaktan öte, sadece "insan karşıtı merkezli" olduğu iddia edilmektedir (Pepper, 1999, s. 30).

Doğa kaygısı ile hümanizmi nasıl bağdaştırılabilir? Derin ekolojinin bakış açısından, kendi kendisinden korunması gereken, dünyanın merkezi olarak düşünülen insan değil, ama bu haliyle ve insanlara karşı savunulmak zorunda olan kozmos'tur. Sonuçta, ekosistem -biyosfer- insan olarak adlandırılan bu zararlı türden çok daha üstün bir içsel değerle donatılmış durumdadır (Ferry, 2000, s. 20, 26).

İnsan dişındaki doğal hayatın gelişmesi için insan nüfusunun azaltılması gereği üzerinde durulması, derin ekolojinin insan sevmezliğinin bir göstergesi olarak değerlendirilmektedir. Bramwell, derin ekolojiyi hümanizm karşitı bir ekoloji biçiminde nitelendirmektedir. Ona göre, derin ekolojinin insana bakışı, "doğal bir yıkıcı, tahripkâr bir virüs" şeklindedir (Bramwell, 1994, s. 161). Derin ekoloji, insana/topluma ait değerler sistemine güvenmemektedir. Çünkü insan kusurlu, defolu bir varlıktır. Onun eğilimi, ekosistemin istikrarını bozmaya yöneliktir. İnsanın özündeki bu manevî kusur, geliştirdiği toplumsal yapılara, medeniyete, tarıma, teknolojiye, dine, vb. yansımıştır. O nedenle derin ekolojinin dayandığı ahlâkî değerler ve eylem programına yön veren ilkeler, insan tarafından üretilen değerler sisteminin dışındadir.

Biyosferik eşitlik ile biyo-merkezci yaklaşım arasındaki çelişkiye işaret eden Mellor (1993, s. 104), derin ekolojinin, bütün varlıkların eşitliğini savunduğu halde, doğal dünyanın örgütlenme ilkelerini toplumsal örgütlenme ilkelerine üstün tuttuğunu belirtmektedir. Bütüne ait parçaların hepsi ontolojik düzeyde eşittir, ancak parçalardan biri (insan) ile bütün (doğal dünya) ve bu ikisinin ihtiyaçları arasında bir çelişki sözkonusudur. Derin ekoloji, önce- 
liği doğal dünyanın ihtiyaçlarına vermektedir. Bu bağlamda biyo-merkezcilik, hümanizm karşıtı bir potansiyel içermektedir. Luke (1988, s. 71-72)'a göre derin ekoloji, açık bir biçimde "Aydınlanmacı şemanın sistematik reddi"dir. Derin ekolojinin inşa etmeye giriştiği insan ile doğa arasındaki yeni ahlâkî ilişki, metafizik bilgi, doğanın 'canlı' kavramlaştırılması ve Aydınlanma karşıtı muhakeme tarzı üzerinde yükselmektedir. Doğaya beslenen aşk ile insana duyulan nefret arasında ince bir çizgi olduğu şüphe götürmez.

\section{Sonuç Yerine: İnsan Dışında Siyasal Bir Özne Mümkün Olabilir mi?}

Bugün ekolojizm etrafında, canlı hakları, hayvan hakları gibi kategoriler üzerinden gelişen tartışmanın odağındaki soru şudur: Hukukun yegâne öznesi insan mıdır, yoksa biyosfer, ekosfer geçmişteki adlandırmayla 'kozmos' da hukukun kapsama alanına dâhil edilmeli midir? Eğer insan dışındaki dünya da hukukun kapsamı içine alınacaksa insan, ontolojik, etik ve hukuksal bakımdan başkaları arasında bir öğeden ibaret hâle gelecektir. Eğer öyleyse insan ve insan dışındaki dünya arasında kaybolan uyumu yeniden kuracak bir doğa sözleşmesine ihtiyaç var demektir. Bu ihtiyaç, hümanist bir hukuk görüşünden kozmik bir hukuk görüşüne geçişi çağırmakta, daha ötesi zorlamaktadır. Esasen doğayla sözleşme nosyonunun bizi götüreceği nihaî nokta, bütün biçimleriyle hümanizmin tasfiyesi, aşılmasıdır. Doğayla sözleşme çağrısı, bir anlamda, insanlık tarihinin bir aşaması olarak hümanizmanın paranteze alınması talebidir.

Serres, 'Doğayla Sözleşme'yi bir zorunluluk olarak görmektedir. Zorunluluğu, doğa ve insan arasında süregiden 'savaş'la temellendirmektedir. Nasıl ki toplum sözleşmesi insanlar arasındaki savaşa son vererek barışın nasıl sağlanacağının yolunu göstermektedir, doğayla sözleşme de insanla doğa arasındaki savaşı nihayete erdirecek, barışı sağlayacaktır:

İlkel toplum sözleşmesini yeniden gözden geçirmenin ve hattâ yadsımanın gerekliliği. Bu sözleşme, bizi, iyi ve kötü günde, dünyanın yer almadığ birinci köşegen boyutunda birleştiriyor; şimdi, tehlike karşısında birleşmeyi öğrendiğimize göre, öteki köşegen boyunca, dünya ile imzalanması gereken yeni bir ittifak gerekiyor: doğayla sözleşme. (Serres, 1994, s.27)

Toplum sözleşmesi fikri, siyaset öncesi doğal/ilkel hâl ile sözleşme sonrası inşa edilen siyasal toplum arasındaki farkı, barbarlık-uygarlık ikilemi içinde açılar. Doğa durumundan çıkış, savaştan barışa, siyaset öncesinden siyasete, barbarlıktan uygarlığa geçişle eş anlamlıdır. Toplum sözleşmesinin siyaset ya 
da barbarlık biçiminde kurduğu denklem, bugün doğayla sözleşme cephesinden ekoloji ya da barbarlık biçiminde kurulmaktadır. Serres (1994, s.48), tarihin bugünkü çatallanışını "ölüm ya da ortak yaşam" ikiliği üzerinden formüle etmektedir.

Buradaki can alıcı, kritik sorular şöyle formüle edilebilir: İnsan dışındaki dünyanın siyaseten özneleşmesi pratikte nasıl gerçekleşecek? İnsan dışındaki dünya, kendi iyiliğini, kendi çıkarlarını, 'gezegensel ortak iyi'sini nasıl ifade edecek? Bunları sağlamaya dönük siyasal eylemini nasıl kurgulayacak? Esasen bu sorulara ekolojistlerin, doğayla sözleşmeyi savunanların insana sınır koyma, insanı insan dışındaki dünya ile sorumlu ve ahlâkî bir ilişkiye dâvet etme dışında bir cevap vermediklerini biliyoruz. Bu soruları cevaplamaya dönük her teşebbüsün, kaçınılmaz olarak, doğal olanın ne olduğuna, 'doğanın sesi'nin bize ne söylediğine, doğanın örtük mesajının ne olduğuna dair içinden çıkılması zor tartışmaları beraberinde getirdiği, getireceği muhakkak.

Son söz olarak Bookchin (1996, s.153)'e referansla şu gerçeğin altını çizmekte fayda var: Özellikle derin ekolojistlerin 'kendini gerçekleştirme' ve 'biyosferik eşitlik' hakkı üzerinden doğaya yaptıkları yüklemeler, toplumsal dünyaya ait kavramların doğal dünyaya yansitılmasından öte pratik bir anlam taşımamaktadır. Zira baştan beri ifade ettiğimiz gibi, insan-doğa ilişkisinde ulaşabileceğimiz 'doğal' bir doğa mevcut değildir. Daha ötesi, ekolojik siyasetlerin insan eylemini muhayyel bir 'doğa' ekseninde tasarlama teşebbüsünün dışına çıkamaması, ciddi bir demokrasi sorununu da beraberinde getirmektedir. Doğanın ve hayvanların korunmasına yönelik insanlığın gördüğü en gelişmiş yasal düzenlemelerin Nazi rejiminin eseri olduğu ve bunun bir tesadüf olmadığı unutulmamalıdır. 


\title{
Extended Abstract
}

\section{The Natural Contract: Possibility of Eco-centric Politics}

\author{
Tuncay Önder \\ Ankara Hacı Bayram Veli University \\ ORCID: 0000-0003-1266-8756
}

In the preface to his book The New Ecological Order, Luc Ferry mentions various judgments that took place in the mid-16th century and where one of the sides was the "non-human world". In these cases seen in the church, field mice or pests are one of the parties to the cases. According to Ferry, these cases agreement with a non-human part of nature is the first example of, in other words natural contract. These cases express a pre-modern, pre-human form of legal relationship. Appointment of an attorney to animals, subpoena for animals, anathema demand for animals are not the issues that modern-humanist law may include. However, before even a century has passed, in Hobbes's Leviathan, which put forward the theory of the modern state, we encounter a social contract that does not take into account the non-human world because the emergence of modern physics has pushed traditional cosmology out of history. Locke's and Rousseau's contracts also do not recognize the non-human world.

This article contextualizes the concept of natural contract with and the deep ecology current which has had an effort to form a coherent view of the subjectification of nature since the 1980s in. The focus of the debate around the concept of the natural contract: Is human being the sole subject of law, or should the biosphere/ecosphere be included in the law? If the non-human world is to be accepted as a legal subject, human will become an element ontologically and morally among others. The idea of deep ecology and the natural contract sees the solution of the ecological problem in making the world outside the human being a self and therefore a subject of law. This view calls for the transition from a humanist view of law to a cosmic view of law, and further forces it. Essentially, the notion of contract with the nature will lead us to the liquidation of humanism in all its forms. The call for a contract with

idealkent @ C Kent Araştırmaları Dergisi (Journal of Urban Studies)

http://idealkentdergisi.com

Geliş Tarihi Received Date: 30.11.2019 Kabul Tarihi Accepted Date: 25.12.2019 
nature is, in a sense, a demand for parentheses of humanism as a stage in human history. Serres sees the natural contract as a necessity. It is based on the ongoing war between nature and human. How that the social contract shows the way of the transition from war between people to peace, the contract with nature will end the war between human and nature and ensure peace as well. The equation established by the social contract in the form of politics or barbarism is today established in the form of ecology or barbarism from the natural contract front. Serres formulates the present bifurcation of history through the duality of "death" or "symbiosis".

Like any ideology, ecology offers us a narrative of history. In this sense, ecology is the re-reading of history in the axis of nature-human, nature-society relations. But it is necessary to underline a matter that differentiates ecology from all other ideologies. This is because ecology does not only refer to people and society, but also to the principles and norms derived from the natural world other than human. Deep ecology strictly rejects human-centric dualism that separates and differentiates between nature and human. It discusses man and nature as 'one' and 'whole'. Deep ecology derives from the idea that non-human nature has an in itself/inner value; has an eco/bio-centric approach. An eco-centric or bio-centric position necessitates the well-being of the non-human world as well as the well-being of human.

Deep ecology has two final principles. One of them is the principle of selfrealization. Self-realization in the context of deep ecology is a valid right for all beings, both human and non-human not peculiar to human. It refers to the will of human and non-human species to live and develop their potential according to their natural style. The second ultimate principle is the 'biospheric egalitarianism' principle/norm. This principle is the natural consequence of the fact that all life forms have an internal value and equality at the level of self-realization. Biospheric egalitarianism is based on the understanding that human is only a narrow part of life forms. The biospheric egalitarianism norm does not refer to an 'absolute' equation, but to a 'principle' equation. Each species has different needs and potentials, but the species are equal on the basis of the self-realization right. Deep ecology, in the context of the principle of biospheric egalitarianism, leads to a kind of 'bio-democracy by spreading the idea of social egalitarianism in human-centric ethics to the level of biosphere. Thus, it establishes the nature-human relationship on an ethical basis and expands the boundaries of the moral community to include the non-human world. Anti-humanism or misanthrophy is the most important criticism of deep ecology. 
The crucial critical questions can be formulated as follows: How will be the political subjectification of the non-human world realized in practice? How will the non-human world express its own good, its interests, its mutual planetary common good? What will be the method of political action to achieve them? Essentially, we know that ecologists, those who advocate natural contract, do not answer anything other than limiting human beings and inviting them to a responsible and moral relationship with the non-human world. Any attempt to answer these questions will inevitably lead to difficult discussions about what is natural, what 'the voice of nature' tells us, and what the implicit message of nature is.

Finally, with reference to Bookchin, it is important to underline the fact that: in particular, deep ecologists' imposition on nature through the right to 'self-realization' and 'biospheric egalitarianism, has no practical meaning beyond the projection of the social world into the natural world. Admittedly, there is no 'natural' nature that we can refer to when discussing the humannature relationship. Furthermore, the fact that ecological politics cannot go beyond the attempt to design human action on the axis of an imaginary 'nature' raises a serious problem of democracy. It is not a coincidence that the most developed legal arrangements for the protection of nature and animals are the work of the Nazi regime.

\section{Kaynakça/References}

Ağaoğulları, M. A. (Ed.) (2011). Socrates'ten Jakobenlere Batı'da siyasal düş̧ünceler. İstanbul: Illetişim Yayınları.

Barry, J. (1994). The Limits of the shallow and the deep: Green politics, philosophy and praxis. Environmental Politics, 3, 369-394.

Bookchin, M. (1996). Toplumsal ekolojinin felsefesi. İstanbul: Kabalcı Yayınevi.

Bramwell, A. (1989). Ecology in the 20 th century: A history. New Haven, London: Yale University Press.

Bramwell, A. (1994). The fading of the greens: The decline of environmental politics in the West. New Haven: Yale University Press.

Capra, F. (1995). Deep ecology: A new paradigm. Deep ecology for the twenty-first century. G. Sessions (Ed.). Boston: Shambhala Publications, Inc.

Çiğdem, A. (1997). Toplum, doğa ve eko-politik hareketler. Birikim, 98, 31-38.

Dobson, A. (2000). Green political thought. London: Routledge.

Elkins, S. (1994). Mistik ekolojik politika. Birikim, 57-58, 75-86.

Ferry, L. (2000). Ekolojik yeni düzen. (T. IlgazÇev.). İstanbul: Yapı Kredi Yayınları.

Hobbes, T. (2017). Leviathan. (S. Lim Çev.). İstanbul: Yapı Kredi Yayınları. 
Kışlalıŏ̆lu, M. ve F. Berkes. (1990). Çevre ve ekoloji. İstanbul: Remzi Kitabevi.

Leopold, A. (1991). A land ethic. The green reader. A. Dobson (Ed.). San Francisco: Mercury House, Inc.

Locke, J. (2018). Yönetim üzerine ikinci inceleme. F. Bakırcı (Çev.). Ankara: Eksi Kitaplar. Luke, T. (1988). The Dreams of Deep Ecology. Telos, 76, 65-92.

Manes, C. (1990). Green rage: Radical environmentalism and the unmaking of civilization. Boston: Little, Brown and Company.

Mellor, M. (1993). Sınırları yıkmak: Feminist, yeşil bir sosyalizme doğru. O. Akınhay (Çev.). İstanbul: Ayrıntı Yayınları.

Merchant, C. (1992). Radical ecology: The search for a livable world. New York, London: Routledge.

Naess, A. (1992). Ecology, community and lifestyle: Outline of an ecosophy. Cambridge: Cambridge University Press.

Naess, A. (1994). Derin ekolojinin temelleri. Derin ekoloji. G. Tamkoç (Der.). İzmir: Ege Yayıncilik.

Naess, A. (1995a). Politics and the ecological crisis: An introductory note. Deep ecology for the twenty-first century. G. Sessions (Ed.). Boston: Shambhala Publications, Inc.

Naess, A. (1995b). Self-realization: An ecological approach to being in the world. Deep ecology for the twenty-first century. G. Sessions (Ed.). Boston: Shambhala Publications, Inc.

Naess, A. (1995c). The deep ecological movement: Some philosophical aspects. Deep ecology for the twenty-first century. G. Sessions (Ed.). Boston: Shambhala Publications, Inc.

Naess, A. (1995d). The shallow and the deep, long-range ecology movements: A summary. Deep ecology for the twenty-first century. G. Sessions (Ed.). Boston: Shambhala Publications, Inc.

Pepper, D. (1999). Modern environmentalism: An introduction. London: Routledge.

Rousseau, J. J. (1990). İnsanlar arasındaki eşitsizliğin kaynağı. R. N. İleri (Çev.). İstanbul: Say Yayınları.

Roussopoulos D. I. (1993). Political Ecology: Beyond Environmentalism. Montreal: Black Rose Books.

Serres, M. (1994). Doğayla sözleşme. T. Ilgaz (Çev.). İstanbul: Yapı Kredi Yayınları, Simonnet, D. (1993). Çevrecilik. M. S. Şakiroğlu (Çev.). İstanbul: İletişim Yayınları.

Stark, J. A. (1995). Postmodern environmentalism: A critique of deep ecology. Ecological resistance movements. B. R. Taylor (Ed.). Albany: State University of New York Press.

Ünder, H. (1996). Çevre felsefesi. Ankara: Doruk Yayıncilık.

West, R. E. (1994). Yeranamız Gaia: James Lovelock ve gezegen birliği görüşü. Derin Ekoloji. G. Tamkoç (Der.). İzmir: Ege Yayıncılık.

Zeka, N. (1985). Batı Almanya'da alternatif hareket. İstanbul: Metis Yayınları. 